\title{
REGULATION OF PROLIFERATION AND DIFFERENTIATION OF HUMAN FETAL BONE CELLS
}

\author{
Nathalie Krattinger ${ }^{1}$, Lee A. Applegate ${ }^{2}$, Emmanuel Biver ${ }^{3}$, Dominique P. Pioletti ${ }^{1 *}$ and Joseph Caverzasio ${ }^{3}$ \\ ${ }^{1}$ Laboratory of Biomechanical Orthopedics, Institute of Bioengineering, Ecole Poytechnique Fédérale, Lausanne, \\ Switzerland \\ ${ }^{2}$ Cell Therapy Unit, Department of Musculokeletal Medicine DAL, University Hospital CHUV, Lausanne, \\ Switzerland \\ ${ }^{3}$ Service of Bone Diseases, Department of Rehabilitation and Geriatrics, University Hospital of Geneva, Switzerland
}

\begin{abstract}
During the last decade, extensive research has been performed in the field of orthopedic medicine to develop cell-based therapies for the restoration of injured bone tissue. We previously demonstrated that human primary fetal bone cells (HFBCs) associated with porous scaffolds induced a bone formation in critical calvaria defect; however, the environmental factors regulating their behavior in culture have not been identified. HFBCs (human fetal femur,12 week development) were compared to marrow-derived human mesenchymal stem cells (HMSCs) for their capacity to proliferate and differentiate into osteoblasts under various culture conditions. When cultured in standard $\alpha$ MEM medium, PDGF and FGF-2 increased cell proliferation of both cell types. Investigation of the differentiating capacity of HFBCs and HMSCs in a normal culture medium indicated that HFBCs expressed higher expression levels of RUNX2, OSX, and osteogenic markers compared with HMSCs, while SOX9 was expressed at very low levels in both cells types. However, HMSCs, but not HFBCs enhanced osteoblastic markers in response to osteogenic factors. Surprisingly, BMP-2 with osteogenic factors increased cell numbers and reduced osteoblastic differentiation in HFBCs with the opposite effect seen in HMSCs. Associated with a higher expression of osteoblastic markers, HFBCs produced a higher calcified extra cellular matrix compared with HMSCs. Taken together, data presented in this study suggest that HFBCs have characteristics of osteoprecursor cells that are more advanced in their osteogenesis development compared with mesenchymal stem cells, making fetal cells an interesting biological tool for treatment of skeletal defects and diseases.
\end{abstract}

Keywords: Proliferation, differentiation, fetal bone cells, mesenchymal stem cells, growth factors, environmental conditions.

\author{
*Address for correspondence: \\ D.P. Pioletti \\ Laboratory of Biomechanical Orthopedics \\ Station 15, EPFL \\ CH-1015 Lausanne, Switzerland
}

Telephone Number: +41 216938341

FAX Number: +41216938660

E-mail: dominique.pioletti@epfl.ch

\section{Introduction}

During the last decade, extensive research has been performed in the field of orthopedic medicine to develop cell-based therapies for the restoration of injured bone tissue (Ohgushi and Caplan, 1999; Bianco et al., 2001; Rose and Oreffo, 2002; Mauney et al., 2005; Oreffo et al., 2005; Yoshioka et al., 2007) or the treatment of musculoskeletal disease symptoms related to osteogenesis imperfecta (Horwitz et al., 1999; Horwitz et al., 2001; Horwitz et al., 2002; Chamberlain et al., 2004; Le Blanc et al., 2005). A progressive approach in the field of skeletal tissue engineering is to combine cells with threedimensional porous biocompatible materials or scaffolds with or without appropriate growth factors (Quarto et al., 2001; Hutmacher and Sittinger 2003; Mendes et al., 2004; Montjovent et al., 2004; Montjovent et al., 2005; Weir and $\mathrm{Xu}, 2010$ ).

Adult human bone marrow-derived stem cells, also referred to as multipotent mesenchymal stromal cells or mesenchymal stem cells (HMSCs) (Friedenstein et al., 1976; Caplan and Bruder, 2001; Horwitz et al., 2005) can be easily isolated, expanded (Jaiswal et al. 1997), and induced to differentiate into bone, cartilage, fat and other connective tissues (Owen et al., 1987; Pittenger et al., 1999). The potency of these cells has generated considerable biological and clinical interest for bone tissue regeneration (Krebsbach et al., 1999). However, stromal cell population heterogeneity in culture and the inconsistent definition of their properties have been identified (Phinney et al., 1999). Another source of biological material, fetal tissue-specific cells have been used for cell therapy (Clarkson, 2001; Rosser and Dunnett, 2003). For musculoskeletal tissues, high cellular expression has been shown (Hohlfeld et al., 2005; De Buys Roessingh et al., 2006; Hirt-Burri et al., 2008a). Cell banks were developed from only one donor and their safety was analyzed for clinical trials where these fetal cells were shown to successfully repair skin in acute and chronic wounds and burns in Phase I and II human trials (Quintin et al., 2007; Applegate et al., 2009; Ramelet et al., 2009).

Considering the increasing clinical potential of fetal cells for tissue engineering, human fetal bone cells (HFBCs) have been characterized in vitro. It has been previously shown that these cells proliferated more rapidly than adult primary osteoblasts and could produce a mineralized bone matrix when cultured in an osteogenic medium (Montjovent et al., 2004) or in combination with 
adequate scaffolds (Montjovent et al., 2008). Some of these observations have also been previously reported (Mirmalek-Sani et al., 2006). This group communicated that these cells are multipotent when cultured in appropriate media, a characteristic of progenitor cells. In parallel, we demonstrated the HFBC capability to promote bone repair in vivo when combined with porous scaffolds based on poly(L-lactic acid) (Montjovent et al., 2008), results confirming our clinical studies using human fetal skin cells (Hohlfeld et al., 2005; Hirt-Burri et al., 2008b).

To date, little information is available concerning the behavior of HFBCs in culture and of factors regulating their growth and differentiation. Since these cells have characteristics of progenitor cells (Mirmalek-Sani et al., 2006), we compared their capacity to proliferate and differentiate with those of HMSCs cultured in an osteogenic medium.

\section{Materials and Methods}

\section{Reagents and growth factors}

Phosphate-buffered saline pH 7.4 (PBS), L-glutamine, antibiotics and trypsin/EDTA were obtained from Gibco (Life Technologies, Basel, Switzerland). Fetal bovine serum (FBS), L-ascorbic acid, $\beta$-glycerophosphate, dexamethasone, and type I collagenase were purchased from Sigma-Aldrich (St. Louis, MO, USA). Dulbecco's modified Eagle medium (DMEM), DMEM/Ham's F-12 medium, $\alpha$-modified essential medium ( $\alpha \mathrm{MEM})$, and nonessential amino acids were purchased from Amimed (Bioconcept, Allschwill, Switzerland).

Human recombinant bone morphogenetic protein-2 (BMP-2, $50 \mathrm{ng} / \mathrm{ml}$ ) and Indian hedgehog N-terminus (Ihh, $10 \mathrm{ng} / \mathrm{ml}$ ) were obtained from R\&D Systems (Minnesota, MN, USA); platelet-derived growth factor (PDGF-BB, 10 $\mathrm{ng} / \mathrm{ml}$ ) was purchased from Invitrogen (Carlsbad, CA, USA); fibroblastic growth factor-acidic (FGF-1, $10 \mathrm{ng}$ / $\mathrm{ml}$ ), fibroblastic growth factor-basic (FGF-2, $10 \mathrm{ng} / \mathrm{ml}$ ), epidermal growth factor (EGF, $10 \mathrm{ng} / \mathrm{ml}$ ), and insulin-like growth factor-1 (IGF-1, $10 \mathrm{ng} / \mathrm{ml}$ ) were purchased from Sigma-Aldrich, parathyroid hormone-like related protein (PTHrP, $10 \mathrm{ng} / \mathrm{ml}$ ) was obtained from Promokine (Heidelberg, Germany); Wnt3a and Wnt5a (cmWnt) were isolated from $20 \%$ conditioned medium from L-cells stably transfected with cDNA of either Wnt3a or Wnt5a, respectively. BMP-2 $(50 \mathrm{ng} / \mathrm{ml})$ and CGP77675 $(5 \mu \mathrm{M})$ were generous gifts from Wyeth Research (now Pfizer, New York City, NY, USA) and Novartis (Basel, Switzerland) respectively. Selective inhibitors of MAP kinase pathways (U0126, SB202190 and SP600125) and GO6983 were purchased from TOCRIS (Bristol, UK).

\section{Cell sources}

Human primary fetal bone cells (HFBC) were obtained from our dedicated, consistent banks of bone cells comprising several fetal donors (from 11 to 16 gestational weeks of development). In this study, we analyzed two preparations of HFBCs from human fetal femurs (gestational development: 12 weeks, range 11 to 13 ; and 14 weeks, range 12 to 15 ), following voluntary pregnancy interruptions. Fetal biopsies were obtained in accordance with the Ethical Committee of the University Hospital of Lausanne (Ethical Protocol 51/01). Unless otherwise specified, results presented in this study are derived from the 12-week-old fetal tissue. Similar data were obtained with the 14-week-old fetal bone cells. For comparison, bone marrow-derived human adult mesenchymal stem cells (HMSCs), commercially obtained from Cambrex BioScience (Walkersville, MD, USA), were also investigated in this study.

\section{Isolation of fetal osteoblasts}

Fetal femurs were first placed in DMEM containing 100 $\mathrm{IU} / \mathrm{ml}$ penicillin and $100 \mu \mathrm{g} / \mathrm{ml}$ streptomycin for transport to specialized culture facilities. Cultures of primary HFBC were established by rinsing the entire femoral tissue with sterile PBS containing antibiotics. Afterwards, the entire femur - diaphysis with the two epiphyses (length: 10$15 \mathrm{~mm}$ ) - was mechanically dissected with a scalpel blade, and the resulting small pieces of bones were plated into a $4 \mathrm{~cm}$ Petri dishes containing $2 \mathrm{ml}$ of DMEM medium in a $5 \% \mathrm{CO}_{2}$ humidified atmosphere, supplemented with $2 \mathrm{mM}$ L-Glutamine, 10\% FBS (= medium A) during 24 hours. The following day, the volume of medium A was completed to $10 \mathrm{ml}$ for 7 days. Cell outgrowth from bone tissues (= migrating cells) was observed within 1-5 days under normal culture conditions. These migrating cells continued to develop and proliferate in medium A for 9-15 days with a twice weekly change of medium before expansion and cell bank freezing in 50-100 vials with $2 \times 10^{6}$ cells in each vial at $-80^{\circ} \mathrm{C}$. Vials of cells from specific passages were then expanded for use in experiments.

\section{Cell culture}

HFBCs and HMSCs were maintained by passaging once a week in $\alpha M E M$ culture medium at $37^{\circ} \mathrm{C}$ with a $5 \% \mathrm{CO}_{2}$ humidified atmosphere supplemented with $10 \%$ FBS, 2 $\mathrm{mM}$ L-glutamine, $0.5 \%$ non-essential amino acids (vol/ vol), $100 \mathrm{IU} / \mathrm{ml}$ penicillin and $100 \mu \mathrm{g} / \mathrm{ml}$ streptomycin. Culture medium was changed twice a week. When reaching confluence, cells were detached using trypsinEDTA and seeded at $3 \times 10^{3}$ cells per $\mathrm{cm}^{2}$ in T75 flasks. Both cell types were passaged up to a maximum of 5 times and used from passage 2 to passage 6 . Human osteoblastlike MG-63 cells (American Type Culture Collection, Manassas, VA, USA) were maintained in basal $\alpha$ MEM medium containing supplements. Approaching confluence, after 3-4 days, these cells were detached using trypsinEDTA and used for further studies.

For differentiation experiments, all types of cells were exposed to osteoblastic differentiation promoting factors such as $50 \mu \mathrm{g} / \mathrm{ml}$ L-ascorbic acid, $5 \mathrm{mM} \beta$ glycerophosphate, $100 \mathrm{nM}$ dexamethasone, with or without $50 \mathrm{ng} / \mathrm{ml} \mathrm{BMP}-2$.

\section{Measurement of cell replication}

To determine the influence of culture conditions on HFBCs and HMSCs proliferation, cells were seeded at 6000 cells/ $\mathrm{cm}^{2}$ in 12-well multi-plates containing one of the three different media (DMEM, DMEM/Ham's F-12, or $\alpha$ MEM) containing $10 \%$ FBS, $2 \mathrm{mM}$ L-glutamine and antibiotics 
(= proliferation media). Every third day, up to 20 days, cells were washed with PBS, detached with type I collagenase and trypsin-EDTA, and counted by cell counting (Cell Coulter counter; BeckmanCoulter, Brea, CA, USA). Growth factors, investigated here (mentioned above), were tested on cells maintained in $\alpha$ MEM with $3 \%$ FBS for 48 hours. When various inhibitors of signaling pathways were investigated for the response to BMP-2, agents or vehicle (DMSO) were added $15 \mathrm{~min}$ before incubation with BMP-2.

\section{RNA extraction and cDNA synthesis}

Cells were first seeded in 12-well multi-plates containing QMEM culture medium until $90 \%$ confluence, and switched to $\alpha M E M$ osteogenic medium for 10 days. Total RNA was extracted from cell layers using the Trizol reagent as described in the manufacturer's instructions (Invitrogen) and subjected to DNAse I (DNA-free kit, Ambion, Cambridge, UK). Extracted RNA was then reverse transcribed using the multiscribe reverse transcriptase synthesis system (Roche Molecular Systems, Branchburg, NJ, USA).

\section{Real-time quantitative PCR}

After RNA extraction and cDNA synthesis, quantitative RT-PCR reactions were performed with the SYBR Green PCR Master Mix method (Applied Biosystems, Warrington, UK). Amplifications were monitored with the Applied Biosystems Step One Plus ${ }^{\mathrm{TM}}$ real time PCR System for primers described in Table 1. Gene expression values were calculated using the comparative threshold cycle $\left(2^{-\Delta \Delta C T}\right)$ method, normalized to the housekeeping gene GAPDH expression, and compared with the $\Delta \mathrm{CT}$ calibrator value from the untreated group. Results of three combined measurements have been presented (each sample in duplicates) and expressed as mean \pm SEM.

\section{Alkaline phosphatase activity assay}

Alkaline phosphatase activity (ALP) was determined by $p$-nitrophenyl phosphate reaction. Briefly, cells were seeded at 6000 cells $/ \mathrm{cm}^{2}$ in 12-well multi-plates and incubated for 24 hours at $37^{\circ} \mathrm{C}$ in a humidified, $5 \% \mathrm{CO}_{2}$ atmosphere in proliferation medium. At $90 \%$ confluence, cells were exposed to the osteogenic medium with or without $50 \mathrm{ng} / \mathrm{ml}$ BMP-2 for one week. The medium was renewed after three days. Cells were detached from the plate with a cell scraper, harvested in $1 \mathrm{ml}$ of distilled water and disrupted by sonication. The homogenate was centrifuged at $5000 \mathrm{rpm}$ at $4^{\circ} \mathrm{C}$ for 5 minutes, and ALP was determined in the supernatant using $100 \mathrm{mM} p$ nitrophenyl phosphate at $37^{\circ} \mathrm{C}$. The product was measured at $405 \mathrm{~nm}$, and ALP activity was normalized to the total protein content determined by a Micro BCA protein assay (Socochim, Pierce, Lausanne, Switzerland).

\section{Histological analysis}

Paraffin wax sections of $10 \mu \mathrm{m}$ from a human fetal femur (12-week-old development) were first deparaffinized and hydrated with water. Sections were stained in Mayer's hematoxylin solution, washed and counterstained in Resorsin to visualize the cell distribution and morphology, and different tissue structures.

\section{In vitro extracellular matrix mineralization}

Cells were seeded at 6000 cells $/ \mathrm{cm}^{2}$ in $35 \mathrm{~mm}$ Petri dishes in basal $\alpha$ MEM medium containing $10 \%$ FBS with or without BMP-2 $(50 \mathrm{ng} / \mathrm{ml})$, antibiotics and $2 \mathrm{mM}$ glutamine for 4 days. Mineralization was induced by culturing confluent monolayer cells in the osteogenic medium for 21 days. The medium was changed twice a week. In vitro mineralized nodule formation was evaluated using the Alizarin Red Staining (ARS) method (Gregory et al., 2004). ARS was prepared in distilled water at a

Table 1. Primer sequences of human genes used for quantitative PCR analysis

\begin{tabular}{|c|c|c|c|}
\hline Gene & Accession number & Primer sequence: sense/antisense & Amplicon \\
\hline$\overline{G A P D H}$ & NM_002046 & $\begin{array}{l}\text { 5' AACTTTGGTATCGTGGAAGG 3', } \\
\text { 5' CAGTAGAGGCAGGGATGATGT 3' }\end{array}$ & 114 bp \\
\hline$A L P$ & NM_000478 & $\begin{array}{l}\text { 5' GCCTACCAGCTCATGCATAAC 3', } \\
\text { 5' GAAGTGGGAGTGCTTGTATCT 3, }\end{array}$ & $193 \mathrm{bp}$ \\
\hline COL1A1 & NM_000088 & $\begin{array}{l}\text { 5' ACTGGTGAGACCTGCGTGTA 3' } \\
\text { 5' CCAGTCTGCTGGTCCATGTA 3' }\end{array}$ & $263 \mathrm{bp}$ \\
\hline OCN & NM_199173 & $\begin{array}{l}\text { 5' CTCACACTCCTCGCCCTATT 3, } \\
\text { 5, GCTCCCAGCCATTGATACAG 3, }\end{array}$ & $167 \mathrm{bp}$ \\
\hline OSX & NM_152860 & $\begin{array}{l}\text { 5' GGCACAAAGAAGCCGTACTC 3', } \\
\text { 5' TGGGAAAAGGGAGGGTAATC 3' }\end{array}$ & $164 \mathrm{bp}$ \\
\hline$R U N X 2$ & NM_001024630 & $\begin{array}{l}\text { 5', TTACTGTCATGGCGGGTAAC 3, } \\
\text { 5, GGTTCCCGAGGTCCATCTA 3, }\end{array}$ & $220 \mathrm{bp}$ \\
\hline COL2A 1 & NM_001844 & $\begin{array}{l}\text { 5, TGGCTTCCATTTCAGCTATG 3', } \\
\text { 5' CATCCTTCAGGGCAGTGTAC 3, }\end{array}$ & $245 \mathrm{bp}$ \\
\hline SOX9 & NM_000346 & $\begin{array}{l}\text { 5' ACCCGCTCACAGTACGACTA 3', } \\
\text { 5' AGGTCGAGTGAGCTGTGTGTA 3, }\end{array}$ & $223 \mathrm{bp}$ \\
\hline CD44 & NM_000610 & $\begin{array}{l}\text { 5' GCAAACAACACAGGGGTGTA 3' } \\
\text { 5' AGTAGGGTTGCTGGGGTAGA 3' }\end{array}$ & $228 \mathrm{bp}$ \\
\hline CD90 & NM_006288 & $\begin{array}{l}\text { 5' AGTGCTGCATGCGATTATCT 3', } \\
\text { 5' GTACCCCACCATCCCACTAC 3' }\end{array}$ & $218 \mathrm{bp}$ \\
\hline
\end{tabular}



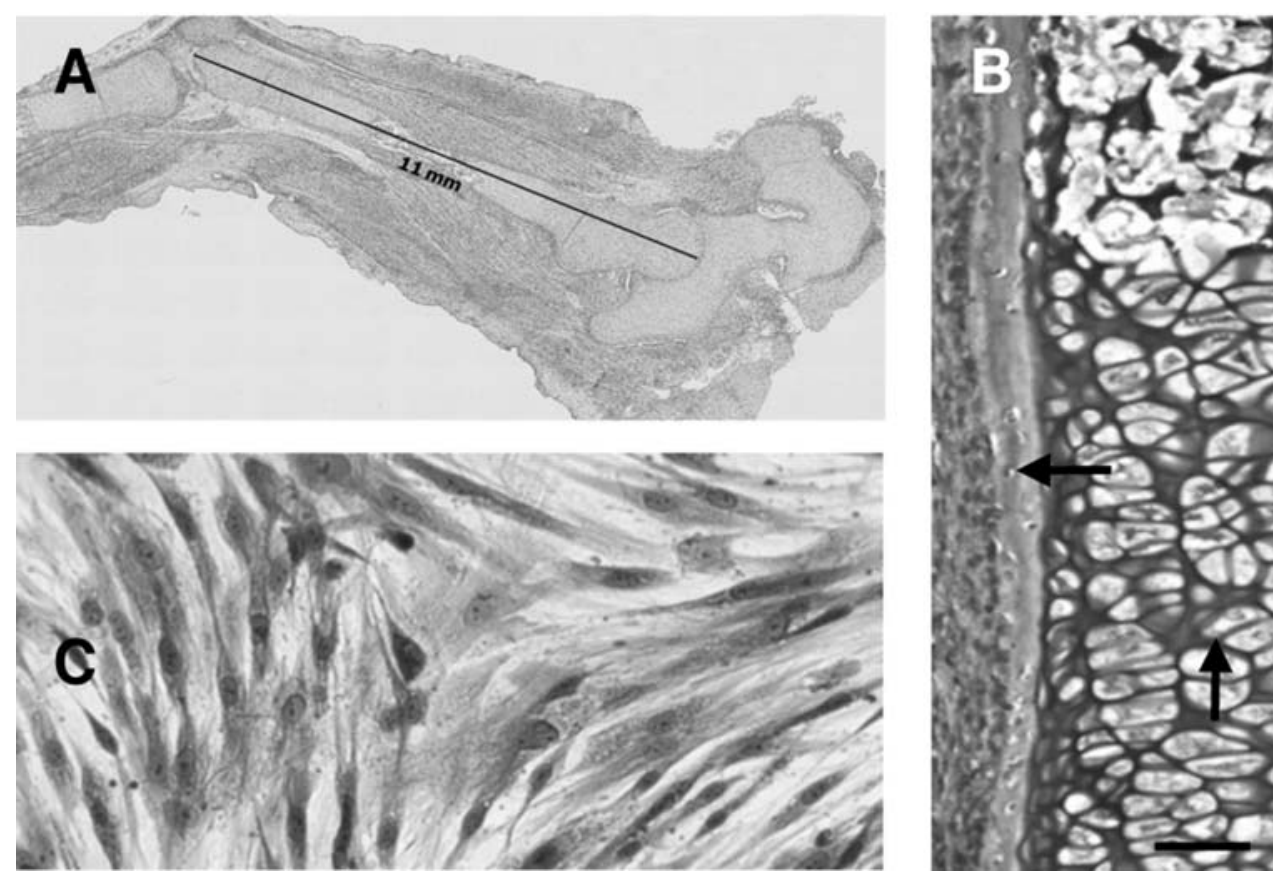

Fig. 1. Human fetal bone cell populations. (A) Human fetal femur (12 weeks development). (B) Hemalun-erythrosine staining showing predominantly cartilaginous tissue. Chondrocytes (vertical arrow) of the diaphysis are surrounded by the perichondrium containing osteoprogenitor cells (horizontal arrow). (C) Culture of bone cells extracted from a 12 week-old fetal femur. Cells appeared elongated with a fibroblastic morphology and formed a homogenous population. Bar $=50 \mu \mathrm{m}$.

concentration of $20 \mathrm{mM} \mathrm{pH} 4.2$ and samples were read at $595 \mathrm{~nm}$ in 96-well plates using a Wallac 1420 VICTOR $^{2}$ multilabel plate reader (Wallac, Turku, Finland).

\section{Statistical analysis}

Data presented are mean \pm SEM of triplicate determinations. Statistical analysis was performed using a one-way ANOVA. A difference between experimental groups was considered to be significant when the probability value was less than $1.0 \%$.

\section{Results}

\section{Morphology of cells isolated from fetal femurs}

Cell populations isolated from a 12-week-old human fetal femur (Fig. 1A) and cultured in basal media appeared as homogenous population of elongated cells with fibroblastic morphology (Fig. 1C). The homogeneity and cell morphology did not change when cells were cultured in an osteogenic medium (data not shown). Histological analysis of this fetal femur (Fig. 1A) indicates that this tissue is essentially populated by chondrocytes at different stages of differentiation with several osteoblastic cell types forming the perichondrium (Fig. 1B).

\section{Cell proliferation of HFBCs and HMSCs}

The requirement of different nutrient-containing culture media for cell proliferation of HFBCs and HMSCs was determined in three standard culture media such as DMEM, DMEM/Ham's F-12 or $\alpha$ MEM supplemented with $10 \%$ FBS. As shown in Fig. 2A, HFBCs and HMSCs grew more rapidly in $\alpha$ MEM medium, compared with the other two media. Cell proliferation was also measured in $\alpha \mathrm{MEM}$ culture medium containing osteogenic factors (dexamethasone, ascorbic acid and $\beta$-glycerophosphate). In this experimental condition, HMSCs grew faster than HFBCs (data not shown). To investigate the role of various growth factors on the proliferation of HFBCs and HMSCs, mitogenic growth factors were exposed to these cells for $48 \mathrm{~h}$ in the standard $\alpha \mathrm{MEM}$ medium. Significant effects on cell number were obtained with FGF-2 and PDGF-BB for both cell types with a higher response for HMSCs (100\%), compared with HFBCs (50\%). FGF1 and PTHrP also enhanced cell numbers in HMSCs but not in HFBCs. Wnt3a, an essential factor for commitment of mesenchymal progenitor cells into osteoprogenitors also significantly increased cell number in HMSCs with a trend in HFBCs, whereas BMP-2 slightly enhanced cell number in HFBCs but not in HMSCs (Fig. 2B).

\section{Osteoblastic phenotype of HFBCs and HMSCs and regulation by osteogenic factors}

To compare the phenotype of HFBCs and HMSCs and their capacity to differentiate into osteogenic cells in presence of osteoinductive factors, expression of several osteogenic and chondrogenic genes were determined after 10 days of culture in either a basic or an osteogenic medium. Compared with HMSCs cultured in basic medium, HFBCs expressed higher levels for RUNX2, ALP, COL1A1 and OCN that are osteoblastic markers (Fig. 3AD). In these cells, the presence of osteogenic factors did not enhance expression of RUNX2, ALP and COL1A1 (Fig. 3A, B and D), and reduced OCN expression (Fig. 


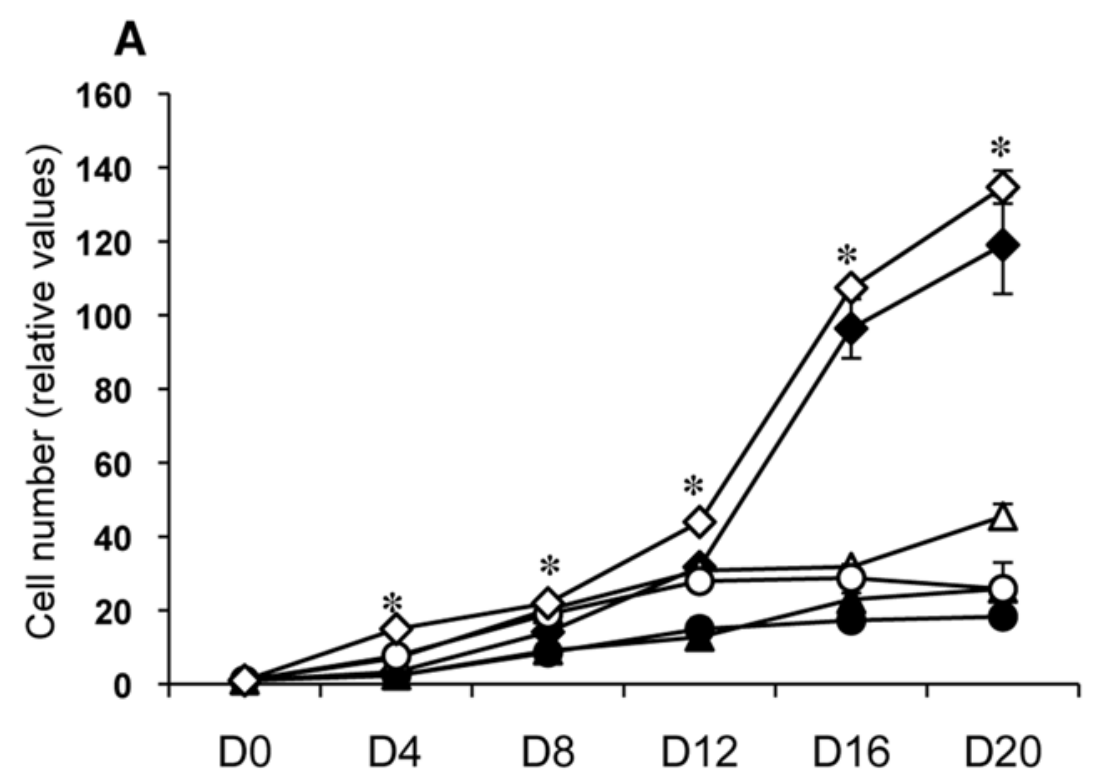

B

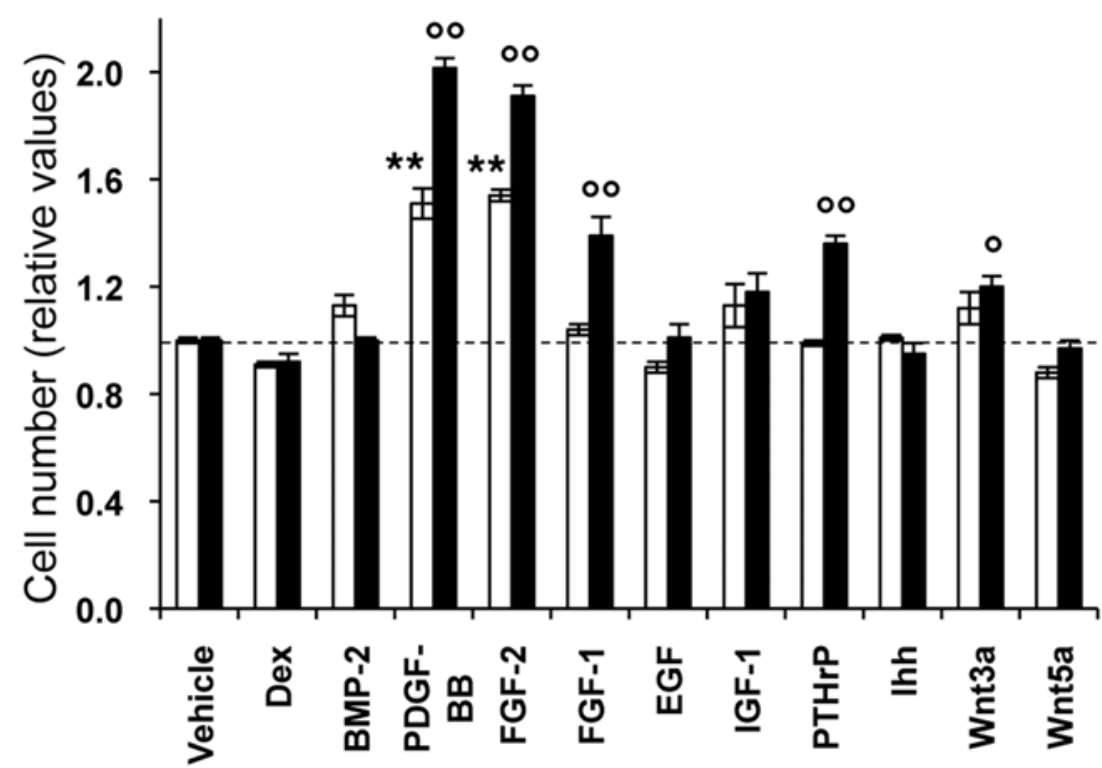

Fig. 2. Effects of culture medium and growth factors on proliferation of HFBCs and HMSCs. (A) Replication curves of human fetal bone cells (HFBCs, empty markers) and mesenchymal stem cells (HMSCs, full markers)

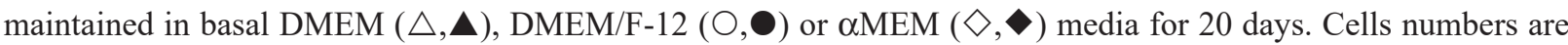
expressed relative to cell counts at day 0. (B) Effects of various growth factors on HFBCs proliferation (white bar) and HMSCs (black bar) in $\alpha$ MEM culture medium (concentrations and incubation time are mentioned in Materials and Methods). Cell numbers are expressed as ratios with their respective controls (incubation with vehicles). Data are presented as mean \pm SEM from triplicate determinations of a representative experiment. $* * p<0.001$, significant from untreated HFBCs; ${ }^{\circ} p<0.01,{ }^{\circ} p<0.001$, significant from untreated HMSCs.

3C), whereas in HMSCs, osteogenic factors increased expression of RUNX2 and COL1A1 (Fig. 3A and D) but not that of ALP and OCN (Fig. 3B and C). Compared with human fetal cartilage-derived cells (HFCCs), expression of the two markers of chondrogenic differentiation SOX9 and COL2A1 was very low or undetectable in both HFBCs and HMSCs (Fig. 3E and F). Both cell types also expressed markers of mesenchymal progenitor cell surface, such as the hyaluronate receptor (CD44) and the thymosin-1 cell surface antigen (CD90), expression that was not markedly changed in presence of osteoinductive factors (Fig. 3G and $\mathrm{H})$.
Effects of BMP-2 on cell proliferation and differentiation of HFBCs and HMSCs

In basic medium, BMP-2 did not influence cell proliferation after $48 \mathrm{~h}$ incubation in both cell types. However, proliferation was significantly decreased by about $20 \%$ in HMSCs with an opposite effect in HFBCs when cultured in the osteogenic medium (Fig. 4A). In HFBCs cultured in basic medium, BMP-2 had little effects on markers of early osteoblastic differentiation such as ALP, RUNX2 and OSX (Fig. 4B, C and D) but markedly decreased expression of the late marker OCN (Fig. 4E). When cultured in the osteogenic medium, the increased 

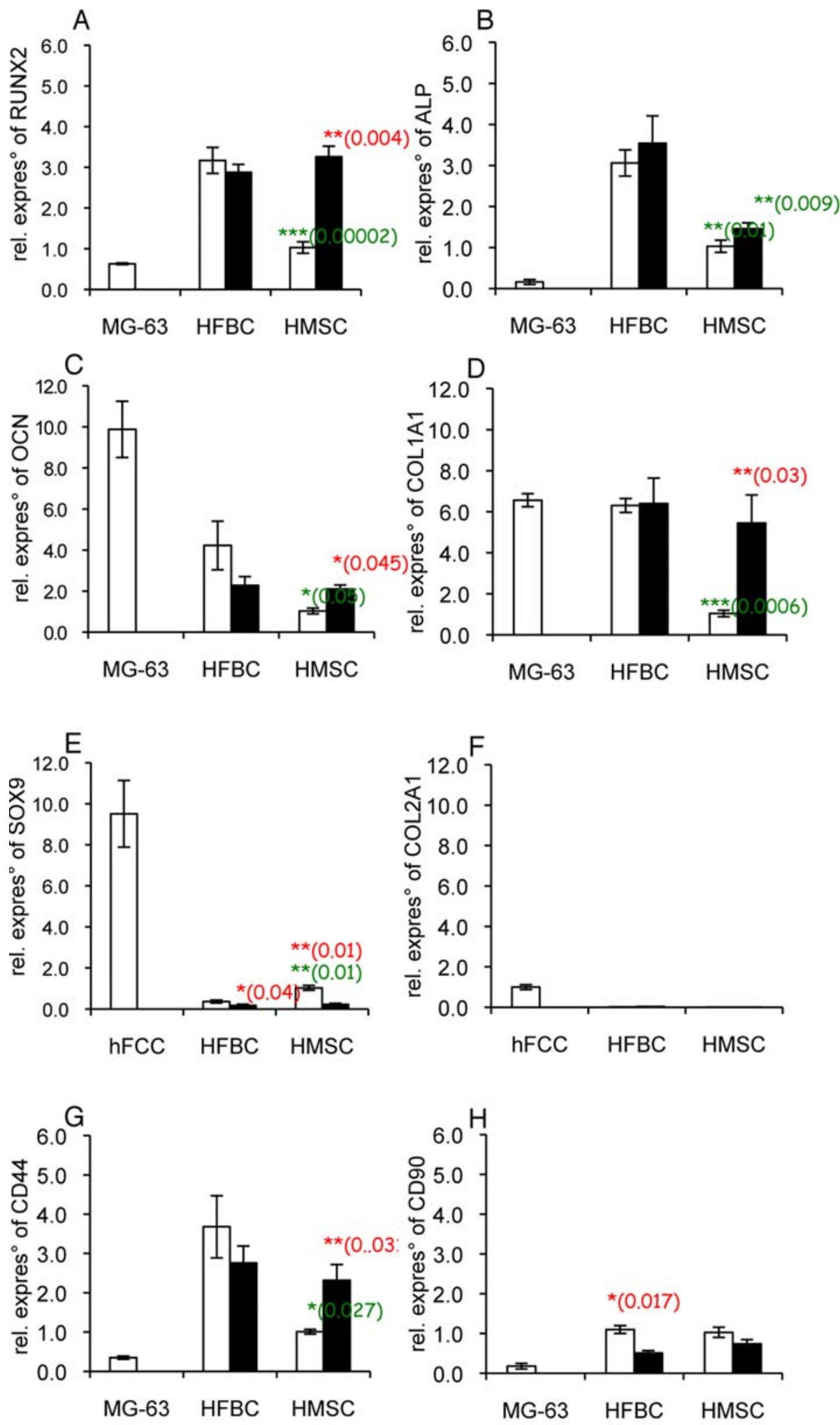

Fig. 3. Quantitative gene expression levels in response to osteogenic factors in HFBCs and HMSCs. Total RNA was extracted in confluent cells and quantitative PCR analysis for RUNX2 (A), ALP (B), OCN (C), COL1A1 (D), SOX9 (E), COL2A1 (F), CD44 (G) and CD90 (H) gene expression was performed. HFBCs and HMSCs were maintained in basal $\alpha$ MEM medium (white bar) or in osteoinductive $\alpha$ MEM medium (black bar) for 10 days. Human fetal cells isolated from mixed cartilage ( $\mathrm{hFCCs}$ ), and cultured in chondrogenic conditions (DMEM supplemented with $2 \mathrm{mM}$ L-glutamine, 1x Insulin-Transferrin-Selenium (ITS), $10 \mathrm{mM}$ sodium pyruvate, $40 \mu \mathrm{g} / \mathrm{ml}$ L-proline, $50 \mu \mathrm{g} / \mathrm{ml}$ ascorbic acid and $10 \mathrm{ng} / \mathrm{ml} \mathrm{TGF}-\beta 3$ ) for 10 days were used as reference for SOX9 and COL2A1 mRNA. MG-63 cell line, maintained in $\alpha$ MEM base medium without any osteogenic factors, served as a control source for osteoblastic markers. mRNA quantification is presented as relative expression of $2^{-\Delta \Delta \mathrm{CT}}$ values. Red figures indicate significant statistical difference between the 2 tested media and green figures indicate significant statistical difference between HFBC and HMSC. 

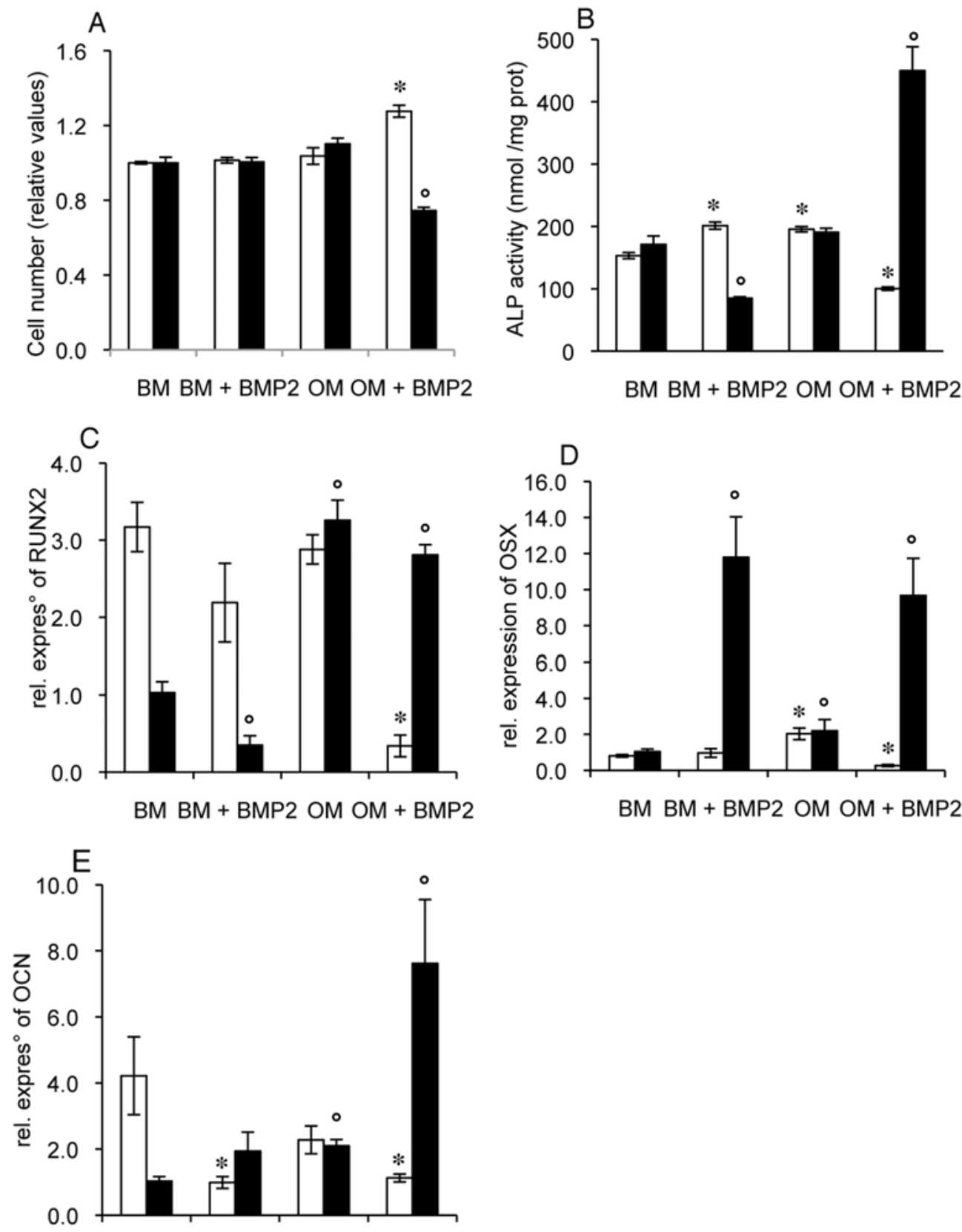

$\mathrm{BM} \mathrm{BM}+\mathrm{BMP} 2 \mathrm{OM} \mathrm{OM}+\mathrm{BMP} 2$

Fig. 4. Effects of BMP-2 on HFBCs and HMSCs. (A) BMP-2 increased HFBCs proliferation. Number of HFBCs (white bars) and HMSCs (black bars) was measured 48 hours after incubation with a single dose of BMP-2 (50 ng/ ml). (B) Regulation of alkaline phosphatase (ALP) activity by BMP-2 in basal medium (BM) and in osteogenic medium (OM) in HFBCs and HMSCs after 10 days of treatment. Culture medium supplemented with BMP-2 was renewed every 3 days. (C-E) Effect of BMP-2 on gene expression. RUNX2 (C), OSX (D) and OCN (E) mRNA levels were quantified by real-time PCR 10 days post-treatment with BMP-2 and/or osteoinducive supplements. Data presented are mean of three independent cultures \pm SEM. ${ }^{*} p<0.01$ versus untreated (BM) HFBCs; ${ }^{\circ} p<0.01$ and versus untreated (BM) HMSCs.

cell number in HFBCs was associated with a decrease in all markers of osteoblastic differentiation (Fig 4B-E). Associated with the decreased cell number induced by BMP-2 in HMSCs cultured in the osteogenic medium, cell differentiation assessed by measurements of ALP and OCN expression was significantly increased (Fig. 4B and E). Surprisingly, expression of RUNX2 was upregulated by osteogenic factors and not by BMP-2 (Fig. 4C) suggesting the implication of a RUNX-2-independent mechanism (Matsubara et al., 2008), whereas BMP-2-induced enhancement of OSX expression was independent of the presence of osteogenic factors (Fig. 4D). These observations strongly suggested that BMP-2 differentially regulates HFBCs and HMSCs.

Molecular mechanism by which BMP-2 enhances cell proliferation in HFBCs

In order to investigate the molecular mechanism by which BMP-2 enhances the proliferation of HFBCs, we first determined the time required for an optimal proliferative 


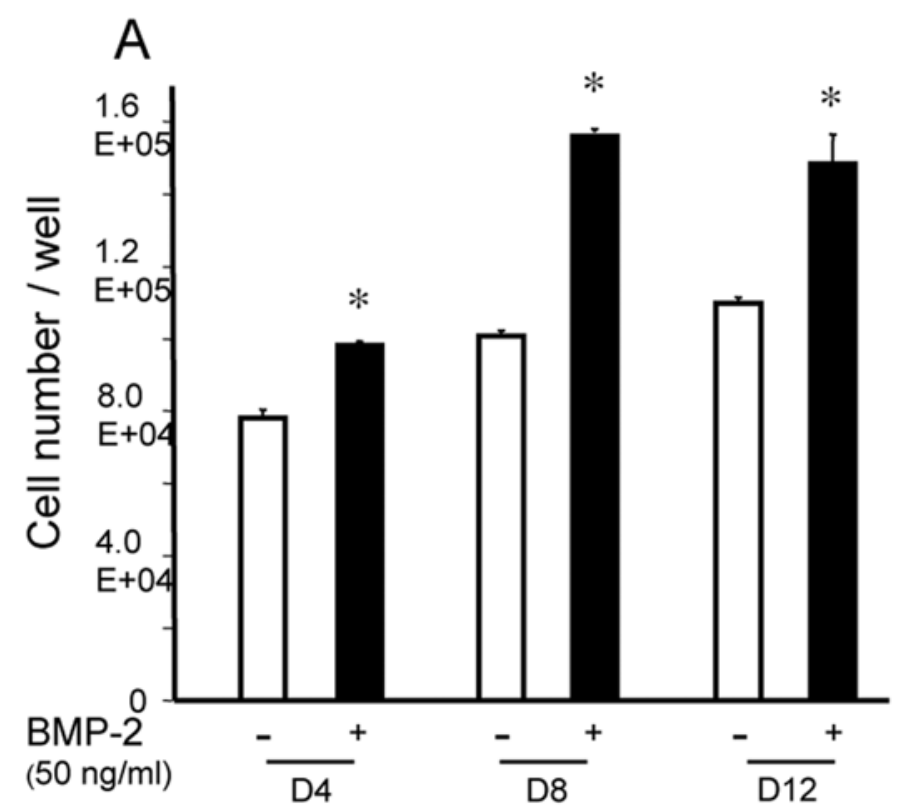

B

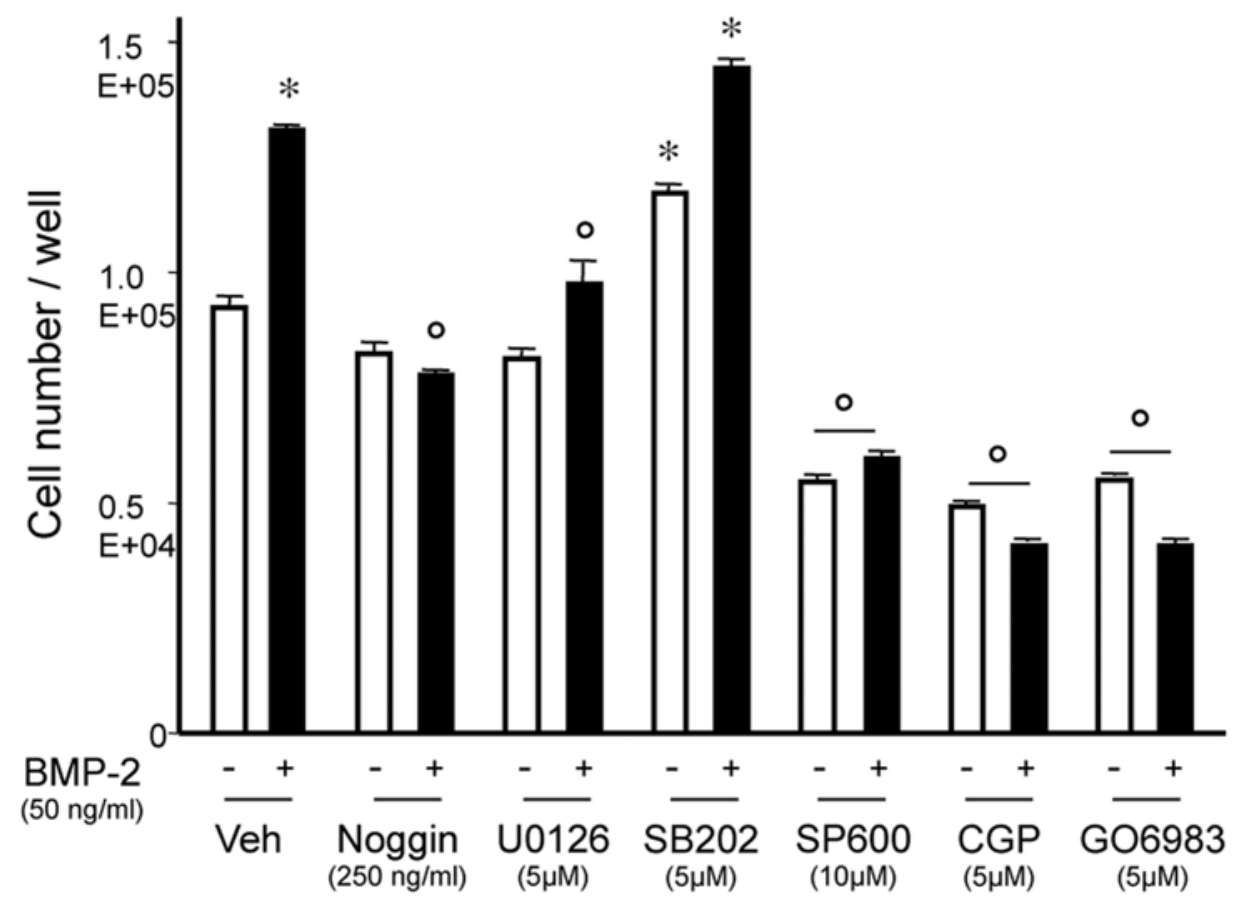

Fig. 5. Time effect of BMP-2 on HFBCs proliferation and analysis of signaling pathways involved in this response. (A) Cells cultured in the osteogenic medium were exposed for various incubation times to BMP-2 (D = days) and cell number was assessed by cell counts. (B) Subconfluent cells cultured in the osteogenic medium were preincubated with either Noggin or various selective signaling pathways inhibitors (U0126= MEK Inhib; SB202190 = p38 Inhib; SP600125 = JNK Inhib; CGP77675 = Src Inhib; GO6983 = PKC Inhib) and then treated with $50 \mathrm{ng} / \mathrm{ml}$ of BMP-2 for 8 days. Cell number was then determined by cell counting. Data presented are mean \pm SEM of triplicate determinations from a representative experiment. ${ }^{*} p<0.01$ compared with the respective control; ${ }^{\circ} p<0.01$ compared with either vehicle or BMP-2 untreated cells.

response (Fig. 5A). After 4 days incubation, cell number was increased by $25-30 \%$ and a maximal effect was observed after 8 days exposure to $50 \mathrm{ng} / \mathrm{ml} \mathrm{BMP-2} \mathrm{(55-}$ $60 \%$ ). For analysis of signaling pathways involved in this response, several selective inhibitors were used and data are presented in Fig. 5B. As expected, the specific BMP-2 antagonist completely inhibited this effect with little effect on basal proliferation. Inhibition of the ERK pathway (U0126) slightly but significantly reduced the BMP-2induced cell proliferation whereas the $\mathrm{p} 38$ inhibitor SB202190 enhanced both the basal proliferation and the BMP-2 proliferation (Fig. 5B). Major inhibitory effects were observed with inhibitors of JNK (SP600125), Src kinases (CGP77675) and PKC (GO6983). These inhibitors 


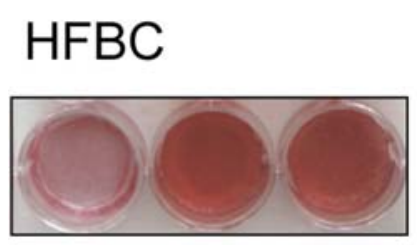

\section{HMSC}
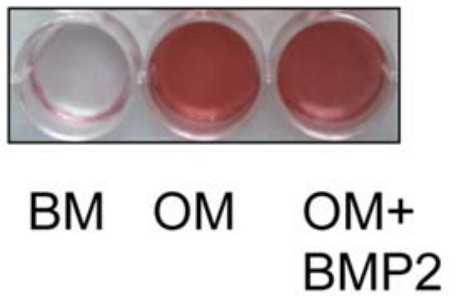

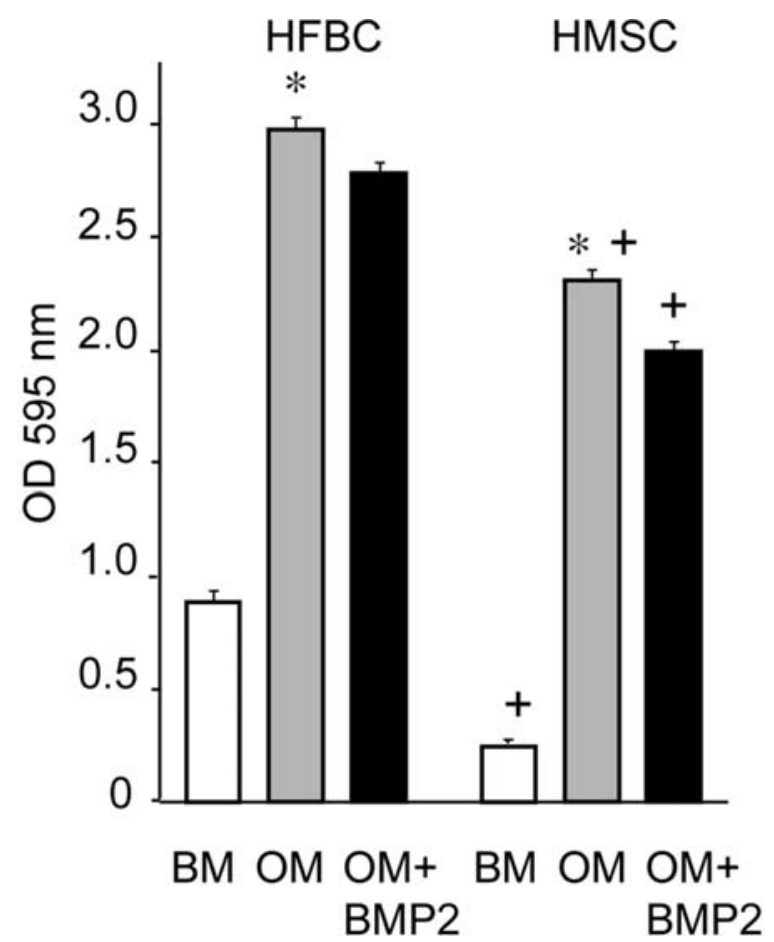

Fig. 6. Osteogenic differentiation of HFBCs and HMSCs. Extracellular matrix mineralization was induced in confluent monolayers of HFBCs and HMSCs cultured either in basal (BM) or osteogenic (OM) medium with or without BMP-2 $(50 \mathrm{ng} / \mathrm{ml})$ for 21 days. Matrix mineralization was evaluated by Alizarin Red (OD 595) staining. Data presented are mean \pm SEM from triplicate determinations of a representative experiment.

not only diminished the BMP-2 proliferative effect but also markedly reduced basal cell proliferation suggesting an important role of these pathways in controlling the proliferation of HFBCs.

\section{In vitro mineralization in HFBCs and HMSCs}

Semi-quantitative analysis of extracellular matrix calcification by Alizarin red staining in both cell types are presented in Fig. 6. After 21 days of culture in an osteogenic medium, the amount of mineral accumulated in the extracellular matrix of HFBCs was higher compared with that of HMSCs. In both cell type, however, there was no stimulatory effect of $50 \mathrm{ng} / \mathrm{ml} \mathrm{BMP-2}$ on this parameter (Fig. 6).

\section{Discussion}

Data presented in this study indicate that cells isolated from 12-14 week old fetal femurs present characteristics of advanced osteoprogenitors compared with human mesenchymal stem cells isolated from bone marrow. They show a similar growth rate in $\alpha$ MEM medium with similar mitogenic responses to growth factors but a different regulation of their proliferation and differentiation by BMP-2. When cultured in an osteogenic medium, they synthesize a higher amount of mineralized matrix compared with HMSCs in association with higher expression of osteoblastic markers. In the isolation procedure, small pieces of the entire femur were deposited in a Petri dish and cells that colonized the surface of the dish were harvested. Even though at that stage of 12-14 weeks development the femur mainly contained chondrocytes and periosteal cell layers (Fig. 1), the isolated population was homogenous with cells having a spindlelike shape, and no expression of chondrocytes markers. It is likely that cells isolated by this method have high migration and proliferation capacities which are characteristics of mesenchymal progenitors ( $\mathrm{Wu}$ et al., 2007).

Thus, it was not surprising that these cells had similar growth and mitogenic factors responses compared with HMSCs. A first biological characterization of HFBCs has already been reported indicating that these cells have a higher capacity to proliferate compared with human osteoblasts and a higher capacity to differentiate in vitro into bone cells compared with mesenchymal cells (Montjovent et al., 2004). In addition, promising results have been presented concerning the use of these cells associated with ceramic reinforced poly(L-lactic acid) structures for bone regeneration (Montjovent et al., 2008). From these observations suggesting a high potential of these cells in tissue engineering, we further investigated the biological characteristics of these cells and determined what are the regulating factors influencing their expansion and differentiation in vitro compared with human mesenchymal cells. A first important new observation was the much higher proliferation of HFBCs in $\alpha$ MEM compared with DMEM or DMEM/Hams-F12, an effect also observed with HMSCs (Fig. 2A). This result could be explained by the different composition of nutrients, for which those contained in $\alpha$ MEM are more appropriate for 
the development and the physiology of fibroblastic-cell types. To date, only one other study has reported on the effect of several growth media on proliferation of fetal femur-derived cells (Mirmalek-Sani et al., 2009). However, these cells were taken at 8 weeks of development (only one in fetal development stage), which thus represents stem cells and not fetal ( $>9$ weeks) by definition. In $\alpha M E M$ medium, we observed that both HFBCs and HMSCs had a similar growth rate and similar responses to PDGF-BB, FGF-2 and to a smaller extent to Wnt3a and IGF-1 (Fig. 2B). They responded, however, differently to FGF-1, PTHrP and BMP-2. The two former growth factors stimulated HMSCs whereas BMP-2 slightly enhanced the proliferation of HFBCs but not that of HMSCs (Fig. 2B). These data are consistent with previous studies reporting that PDGF-BB induced replication and inhibited bone matrix formation in the intermediate osteoprogenitor zone of fetal rat calvariae (Hock and Canalis, 1994), and that FGF-2 maintained undifferentiated progenitor cells in an immature state, allowing in vitro expansion (Martin et al., 1997; Tsutsumi et al., 2001). PDGF-BB and FGF-2 may thus promote the creation of a large pool of fetal osteoblasts, inducing them to differentiate into mature osteoblasts. Further characterization of HFBCs cultured in either a normal $\alpha M E M$ medium or an osteogenic medium has been obtained with analysis of the expression of the earliest markers required for the process of osteoblastogenesis compared with HMSCs. In a normal $\alpha$ MEM medium when cells rapidly expanded in culture, HFBCs expressed higher levels of bone markers such as RUNX2, ALP, OCN and COL1A1 compared with HMSCs (Fig. 3A-D) suggesting that HFBCs are more advanced in their osteogenic program compared with HMSCs. Moreover, both cell types responded differently to osteogenic factors. Whereas HFBCs maintained their differentiation characteristics in presence of dexamethasone and other osteoinductive factors, HMSCs enhanced some of the bone markers such as RUNX2 and COL1A1 in accordance with previous data (Frank et al., 2002). However, the presence of osteogenic factors are necessary for the formation of a significant amount of mineralized tissue in both cell types (Fig. 6), suggesting the crucial role of these factors in the maturation of osteoprogenitor cells to functional osteoblasts, as widely mentioned in the literature (Jaiswal et al., 1997; Montjovent et al., 2004; Montjovent et al., 2005). Finally, HFBCs and HMSCs did not express cartilage markers such as SOX9 and COL2A1 (Fig. 3 E and F). However, CD44 and CD90, two markers of mesenchymal progenitor surface, were present.

As mentioned above, we found that BMP-2 slightly enhanced the proliferation of HFBCs but not that of HMSCs (Fig. 2B). Increased proliferation of some mesenchymal stem cells by BMP-2 has already been reported (Liu et al., 2009; Shoji et al., 2010). Since BMP2 is a potential inducer of bone regeneration (Lecanda et al., 1997), additional experiments were performed to clarify the effects of BMP-2 on HFBCs proliferation and differentiation. Surprisingly, BMP-2 had opposite effects on HFBCs proliferation and differentiation compared with
HMSCs (Fig. 4). The enhanced proliferation in HFBCs was associated with inhibition of bone marker expression, an effect that was more pronounced in presence of osteogenic factors (Fig. 4). This response is typical of mesenchymal cells already committed to a cell lineage. In HMSCs that are less differentiated cells compared with HFBCs, they probably did not differentiate into osteogenic cells when cultured in the basal culture medium, thus explaining the observed decreased ALP activity. When cultured in the osteogenic medium, they started to differentiate into osteogenic cells thus explaining the increased ALP activity in response to BMP-2 (Fig. 4). Surprisingly, these differential effects of BMP-2 between HFBCs and HMSCs did not influence the matrix mineralization capacity of each cell type (Fig. 6), perhaps because the $50 \mathrm{ng} / \mathrm{ml}$ dose was not sufficient compared with other differentiating factors to promote the synthesis of a mineralized matrix.

Analysis of signaling pathways involved in BMP-2induced HFBCs proliferation suggest that Src kinase(s), $\mathrm{PKC}$ and JNK are major transduction pathways involved in controlling basal and BMP-2 induced cell proliferation in these cells. The cellular and molecular mechanisms responsible for inducing either a proliferative or a differentiating response in osteoprogenitor cells remains unclear but may be explained by expression of different receptors of the transforming growth factor- $\beta$ family. BMP initiates signaling upon ligand binding to the high affinity type I BMP signaling receptors, activin-like receptor kinase-1 (ALK-1), ALK-2, ALK-3, or ALK-6 (Miyazono et al., 2001). The level of expression of each receptor and of various partner signaling proteins determines the variety of biological activities induced by BMP proteins. Further investigation will be required to explain the molecular mechanism by which BMP-2 induces HFBCs proliferation.

One of the major advantages of human fetal bone cells (HFBCs) compared to adult MSC is that only one organ donation is enough to treat hundreds of thousands of patients (Applegate et al., 2009). It has been previously shown with human fetal skin cells that variability between cell lines is minimal compared to young and adult cell lines. Cell banking techniques are thus possible to create the one stock of cells for clinical use following extensive testing for safety. There is then no need to evaluate the variability of HFBCs behavior between samples as ultimately, in the clinical application, only one donor source will be used. However, the characterization for this sample will be extensive (Quintin et al., 2007).

In conclusion, HFBCs have a high capacity to migrate and proliferate in $\alpha \mathrm{MEM}$ medium and are more advanced in their osteogenic program compared with HMSCs from the bone marrow strongly suggesting that these cells are osteoprogenitors derived from the periosteum. Their proliferation can be further increased in presence of PDGFBB and FGF-2 as well as by BMP-2 by a cellular mechanism that remains to be investigated. Given their high capacity to proliferate and their expression of osteogenic characteristics in the absence of differentiating factors, these cells are of potential interest for therapeutic use in bone tissue engineering. 


\section{Acknowledgements}

We are grateful to Sabina Troccaz from the Service of Bone Diseases, and Sandra Jaccoud and Corinne Scaletta from the Laboratory of Biomechanical Orthopedics and Cellular Therapy Unit, respectively for their expert technical assistance. We thank also Dr. Maria-Chiara Osterheld from the University Department of Pathology for her help in fetal histology. This project was supported by the Interinstitutional Center for Translational Biomechanics EPFLCHUV-DAL.

\section{References}

Applegate LA, Scaletta C, Hirt-Burri N, Raffoul W, Pioletti D (2009) Whole-cell bioprocessing of human fetal cells for tissue engineering of skin. Skin Pharmacol Physiol 22: 63-73.

Bianco P, Riminucci M, Gronthos S, Robey PG (2001) Bone marrow stromal stem cells: nature, biology, and potential applications. Stem Cells 19: 180-192.

Caplan AI, Bruder SP (2001) Mesenchymal stem cells: building blocks for molecular medicine in the 21 st century. Trends Mol Med 7: 259-264.

Chamberlain JR, Schwarze U, Wang PR, Hirata RK, Hankenson KD, Pace JM, Underwood RA, Song KM, Sussman M, Byers PH, Russell DW (2004) Gene targeting in stem cells from individuals with osteogenesis imperfecta. Science 303: 1198-1201.

Clarkson ED (2001) Fetal tissue transplantation for patients with Parkinson's disease: a database of published clinical results. Drugs Aging 18: 773-785.

De Buys Roessingh AS, Hohlfeld J, Scaletta C, HirtBurri N, Gerber S, Hohlfeld P, Gebbers JO, Applegate LA (2006) Development, characterization, and use of a fetal skin cell bank for tissue engineering in wound healing. Cell Transplant 15: 823-834.

Frank O, Heim M, Jakob M, Barbero A, Schafer D, Bendik I, Dick W, Heberer M, Martin I (2002) Real-time quantitative RT-PCR analysis of human bone marrow stromal cells during osteogenic differentiation in vitro. $\mathrm{J}$ Cell Biochem 85: 737-746.

Friedenstein AJ, Gorskaja JF, Kulagina NN (1976) Fibroblast precursors in normal and irradiated mouse hematopoietic organs. Exp Hematol 4: 267-274.

Gregory CA, Gunn WG, Peister A, Prockop DJ (2004) An Alizarin red-based assay of mineralization by adherent cells in culture: comparison with cetylpyridinium chloride extraction. Anal Biochem 329: 77-84.

Hirt-Burri N, de Buys Roessingh AS, Scaletta C, Gerber S, Pioletti DP, Applegate LA, Hohlfeld J (2008a) Human muscular fetal cells: a potential cell source for muscular therapies. Pediatr Surg Int 24: 37-47.

Hirt-Burri N, Scaletta C, Gerber S, Pioletti DP, Applegate LA (2008b) Wound healing gene-family expression differences between fetal and foreskin cells used for bioengineered skin substitutes. Art Organs 37: 509-518.

Hock JM, Canalis E (1994) Platelet-derived growth factor enhances bone cell replication, but not differentiated function of osteoblasts. Endocrinology 134: 1423-1428.
Hohlfeld J, de Buys Roessingh A, Hirt-Burri N, Chaubert P, Gerber S, Scaletta C, Hohlfeld P, Applegate LA (2005) Tissue engineered fetal skin constructs for paediatric burns. Lancet 366: 840-842.

Horwitz EM, Prockop DJ, Fitzpatrick LA, Koo WW, Gordon PL, Neel M, Sussman M, Orchard P, Marx JC, Pyeritz RE and Brenner MK (1999) Transplantability and therapeutic effects of bone marrow-derived mesenchymal cells in children with osteogenesis imperfecta. Nat Med 5: 309-313.

Horwitz EM, Prockop DJ, Gordon PL, Koo WW, Fitzpatrick LA, Neel MD, McCarville ME, Orchard PJ, Pyeritz RE and Brenner MK (2001) Clinical responses to bone marrow transplantation in children with severe osteogenesis imperfecta. Blood 97: 1227-1231.

Horwitz EM, Gordon PL, Koo WK, Marx JC, Neel MD, McNall RY, Muul L, Hofmann T (2002) Isolated allogeneic bone marrow-derived mesenchymal cells engraft and stimulate growth in children with osteogenesis imperfecta: Implications for cell therapy of bone. Proc Natl Acad Sci USA 99: 8932-8937.

Horwitz EM, Le Blanc K, Dominici M, Mueller I, Slaper-Cortenbach I, Marini FC, Deans RJ, Krause DS, Keating A (2005) Clarification of the nomenclature for MSC: The International Society for Cellular Therapy position statement. Cytotherapy 7: 393-395.

Hutmacher DW and Sittinger M (2003) Periosteal cells in bone tissue engineering. Tissue Eng 9 Suppl 1: S4564.

Jaiswal N, Haynesworth SE, Caplan AI and Bruder SP (1997) Osteogenic differentiation of purified, cultureexpanded human mesenchymal stem cells in vitro. J Cell Biochem 64: 295-312.

Krebsbach PH, Kuznetsov SA, Bianco P and Robey PG (1999) Bone marrow stromal cells: characterization and clinical application. Crit Rev Oral Biol Med 10: 165181.

Le Blanc K, Gotherstrom C, Ringden O, Hassan M, McMahon R, Horwitz E, Anneren G, Axelsson O, Nunn J, Ewald U, Norden-Lindeberg S, Jansson M, Dalton A, Astrom E and Westgren M (2005) Fetal mesenchymal stem-cell engraftment in bone after in utero transplantation in a patient with severe osteogenesis imperfecta. Transplantation 79: 1607-1614.

Lecanda F, Avioli LV, Cheng SL (1997) Regulation of bone matrix protein expression and induction of differentiation of human osteoblasts and human bone marrow stromal cells by bone morphogenetic protein-2. J Cell Biochem 67: 386-396.

Liu SB, Hu PZ, Hou Y, Li P, Cao W, Tian Q (2009) Recombinant human bone morphogenetic protein-2 promotes the proliferation of mesenchymal stem cells in vivo and in vitro. Chin Med J (Engl) 122: 839-843.

Martin I, Muraglia A, Campanile G, Cancedda R, Quarto R (1997) Fibroblast growth factor-2 supports ex vivo expansion and maintenance of osteogenic precursors from human bone marrow. Endocrinology 138: 4456-4462.

Matsubara T, Kida K, Yamaguchi A, Hata K, Ichida F, Meguro H, Aburatani H, Nishimura R, Yoneda T (2008) BMP2 regulates Osterix through Msx2 and Runx2 during osteoblast differentiation. J Biol Chem 283: 29119-29125. 
Mauney JR, Volloch V, Kaplan DL (2005) Role of adult mesenchymal stem cells in bone tissue engineering applications: current status and future prospects. Tissue Eng 11: 787-802.

Mendes SC, Tibbe JM, Veenhof M, Both S, Oner FC, van Blitterswijk CA, de Bruijn JD (2004) Relation between in vitro and in vivo osteogenic potential of cultured human bone marrow stromal cells. J Mater Sci Mater Med 15: 1123-1128.

Mirmalek-Sani SH, Tare RS, Morgan SM, Roach HI, Wilson DI, Hanley NA, Oreffo RO (2006) Characterization and multipotentiality of human fetal femur-derived cells: implications for skeletal tissue regeneration. Stem Cells 24: 1042-1053.

Mirmalek-Sani SH, Stokes PJ, Tare RS, Ralph EJ, Inglis S, Hanley NA, Houghton FD, Oreffo RO (2009) Derivation of a novel undifferentiated human fetal phenotype in serum-free cultures with BMP-2. J Cell Mol Med 13: 3541 3555 .

Miyazono K, Kusanagi K, Inoue H (2001) Divergence and convergence of TGF-beta/BMP signaling. Journal of cellular physiology 187: 265-276.

Montjovent MO, Burri N, Mark S, Federici E, Scaletta C, Zambelli PY, Hohlfeld P, Leyvraz PF, Applegate LL, Pioletti DP (2004) Fetal bone cells for tissue engineering. Bone 35: 1323-1333.

Montjovent MO, Mathieu L, Hinz B, Applegate LL, Bourban PE, Zambelli PY, Manson JA, Pioletti DP (2005) Biocompatibility of bioresorbable poly(L-lactic acid) composite scaffolds obtained by supercritical gas foaming with human fetal bone cells. Tissue Eng 11: 1640-1649.

Montjovent MO, Mark S, Mathieu L, Scaletta C, Scherberich A, Delabarde C, Zambelli PY, Bourban PE, Applegate LA, Pioletti DP (2008) Human fetal bone cells associated with ceramic reinforced PLA scaffolds for tissue engineering. Bone 42: 554-564.

Ohgushi H, Caplan AI (1999) Stem cell technology and bioceramics: from cell to gene engineering. J Biomed Mater Res 48: 913-927.

Oreffo RO, Cooper C, Mason C, Clements M (2005) Mesenchymal stem cells: lineage, plasticity, and skeletal therapeutic potential. Stem Cell Rev 1: 169-178.

Owen ME, Cave J, Joyner CJ (1987) Clonal analysis in vitro of osteogenic differentiation of marrow CFU-F. J Cell Sci 87: 731-738.

Phinney DG, Kopen G, Isaacson RL, Prockop DJ (1999) Plastic adherent stromal cells from the bone marrow of commonly used strains of inbred mice: variations in yield, growth, and differentiation. J Cell Biochem 72: 570-585.

Pittenger MF, Mackay AM, Beck SC, Jaiswal RK, Douglas R, Mosca JD, Moorman MA, Simonetti DW, Craig S, Marshak DR (1999) Multilineage potential of adult human mesenchymal stem cells. Science 284: 143147.

Quarto R, Mastrogiacomo M, Cancedda R, Kutepov SM, Mukhachev V, Lavroukov A, Kon E, Marcacci M (2001) Repair of large bone defects with the use of autologous bone marrow stromal cells. N Engl J Med 344: 385-386.

Quintin A, Hirt-Burri N, Scaletta C, Schizas C, Pioletti DP and Applegate LA (2007) Consistency and safety of cell banks for research and clinical use: preliminary analysis of fetal skin banks. Cell Transplant 16: 675-684.

Ramelet AA, Hirt-Burri N, Raffoul W, Scaletta C, Pioletti DP, Offord E, Mansourian R, Applegate LA (2009) Chronic wound healing by fetal cell therapy may be explained by differential gene profiling observed in fetal versus old skin cells. Exp Gerontol 44: 208-218.

Rose FR, Oreffo RO (2002) Bone tissue engineering: hope vs hype. Biochem Biophys Res Commun 292: 1-7.

Rosser AE, Dunnett SB (2003) Neural transplantation in patients with Huntington's disease. CNS Drugs 17: 853867.

Shoji T, Ii M, Mifune Y, Matsumoto T, Kawamoto A, Kwon SM, Kuroda T, Kuroda R, Kurosaka M, Asahara T (2010) Local transplantation of human multipotent adipose-derived stem cells accelerates fracture healing via enhanced osteogenesis and angiogenesis. Lab Invest 90: 637-649.

Tsutsumi S, Shimazu A, Miyazaki K, Pan H, Koike C, Yoshida E, Takagishi K, Kato Y (2001) Retention of multilineage differentiation potential of mesenchymal cells during proliferation in response to FGF. Biochem Biophys Res Commun 288: 413-419.

Weir MD, Xu HH (2010) Culture human mesenchymal stem cells with calcium phosphate cement scaffolds for bone repair. J Biomed Mater Res B Appl Biomater, in press.

Wu Y, Wang J, Scott PG, Tredget EE (2007) Bone marrow-derived stem cells in wound healing: a review. Wound Repair Regen 15 Suppl 1: S18-26.

Yoshioka T, Mishima H, Ohyabu Y, Sakai S, Akaogi H, Ishii T, Kojima H, Tanaka J, Ochiai N, Uemura T (2007) Repair of large osteochondral defects with allogeneic cartilaginous aggregates formed from bone marrowderived cells using RWV bioreactor. J Orthop Res 25: 1291-1298.

\section{Discussion with Reviewers}

Reviewer I: Please explain the potential pros and cons of the human fetal bone cells compared to marrow-derived human mesenchymal stem cells.

Authors: One of the major advantages of human fetal bone cells (HFBCs) compared to adult mesenchymal stem cells (MSCs) is that only one organ donation is enough to treat hundreds of thousands of patients. It has been previously shown with human fetal skin cells that variability between cell lines is minimal compared to young and adult cell lines and thus "pooling" of cell lines would not be necessary and even undesired. Cell banking techniques are thus possible to create the one stock of cells for clinical use following extensive testing for safety which is required for the development of a therapeutic product. There is then no need to evaluate the variability of HFBCs behavior between samples as ultimately, in the clinical application, only one donor source will be used. However, the characterization for this sample will be extensive.

Reviewer I: In general, proliferation of a cell precedes its differentiation. How do you explain the opposite behavior of HFBC and HMSCs upon BMP2 stimulations? 
Authors: It is correct that in general, proliferation of a cell precedes its differentiation. However, at early stages of mesenchymal cell differentiation, cells just may slow down their differentiation and continue their proliferation. The different behavior of HFBCs and HMSCs to BMP2 stimulation is probably related to their different stage of differentiation. HFBCs are at an early stage of osteoblastic differentiation and at that stage, BMP2 induces an increased proliferation associated with a lower ALP activity. In HMSCs that are undifferentiated mesenchymal cells, BMP2 induced their differentiation and this effect is associated with a lower proliferation.

Reviewer I: Human fetal bone cells may be quite well tolerated in their fetal state, perhaps due to low level expression of major histocompatibility complex "tissue antigens". But what about the differentiated cells: do they not start to express MHC molecules, which can evoke immunological rejection and may necessitate immunosuppression of the recipient to improve graft survival?

Authors: Effectively, we showed that human fetal bone cell have a reduced expression of HLA-1 compared to adult osteoblasts (Montjovent et al., 2009). When fetal bone cells stimulated toward osteoblast differentiation, we did not see an increased expression of HLA-1. We cannot exclude though that the expression of HLA-1 increased when the cells are more differentiated. However, this should not represent a problem as the target of fetal cell therapy is to use them as initial growth factor reservoir to induce bone formation and not to produce bone extracellular matrix. The delayed immunological rejection would then not affect the initiation of bone healing through the release of growth factors by the fetal cells. Additionally, clinical trials with fetal skin cells in humans did not show any sign of immune rejection even following multiple treatments.

Reviewer II: How do the authors explain the effect of BMP-2 in HMSCs, regarding ALP activity (in base medium it decreases but in osteogenic medium it increases sharply)?

Authors: In basal medium, HMSCs have the potential to differentiate into various cell types. Therefore, the decrease of ALP activity suggests that when cultured in this medium, HMSCs were not differentiating into osteoblastic or chondrogenic cells and thus explaining the decreased ALP. When cultured in the osteogenic medium, they differentiated into osteogenic cells therefore explaining the increased ALP activity.

Reviewer II:- Based on Fig. 6B, although the mineralization was higher in HFBCs, in absolute terms, when compared with HMSCs it is not like that. In fact, the mineralization in base medium is about $50 \%$ lower in HMSCs, that is, the increase caused by osteogenic medium in that condition was higher than in HFBCs cultures. Please comment.

Authors: It is correct that the increase in mineralization between basal and osteogenic medium was higher in
HMSCs compared with HFBCs. This is due to the more advanced phenotype of HFBCs compared with HMSCs with higher basal mineralization activity in basal medium of HFBCs. Since both cell types are derived from the same progenitor cells, they reach similar osteoblastic activity when cultured in optimal osteogenic conditions.

Reviewer II: The authors say that HFBCs express higher levels of osteoblastic markers than HMSCs, which lines with a higher commitment to osteoprogenitor differentiation. However, the growth rates of HFBCs and HMSCs are similar. Please comment on this situation, because usually, proliferation decreases with the degree of differentiation.

Authors: In general, an increase in osteoblastic cell proliferation is associated with a decrease in cell differentiation. This association, however, is not always observed in mesenchymal stem cells which often have the potency to commit themselves to a cell phenotype while keeping a high capacity to proliferate. In HFBCs, BMP2 effectively induced a proliferative response and during cell replication, the bone differentiation parameters were decreased. An opposite response was observed in HMSCs which are cells less differentiated compared with HFBCs. This type of response is also observed in the ST2 mesenchymal cell line in response to Wnt3a and BMP-2 (personal observations). In these cells, Wnt3a and BMP-2 induce both an increase in proliferation and a marked increase in alkaline phosphatase activity. Thus, whereas it is generally accepted that proliferating cells decreased their differentiating potential, undifferentiated mesenchymal cells have the capacity to differentiate while still proliferating.

Reviewer II: The presence of osteogenic medium seems not to affect ALP, Runx2 and Col1A1 expression in HFBCs, and OCN expression is even lowered in those conditions. However, when we observe Fig. 6, there is a clear stimulation of osteoblastic differentiation induced by osteogenic medium. How is this possible?

Authors: Analysis of osteoblastic marker expression has been performed at day 10 in culture probably representing an early stage of differentiation. Marker expression probably increases later during the differentiation process. The time course of this expression is likely to be different between the two cell types and difficult to assess since it probably varies between experiments. Matrix mineralization is an appropriate measure of cell differentiation that integrates all processes leading to a calcified matrix.

\section{Additional Reference}

Montjovent MO, Bocelli-Tyndall C, Scaletta C, Scherberich A, Martin I, Laurent-Applegate L., Pioletti DP (2009) In vitro characterization of immune-related properties of human fetal bone cells for potential tissue engineering applications. Tissue Eng 15: 1523-1532. 